\title{
Optimized and Validated Spectrophotometric Methods for the Determination of Lisinopril in Pharmaceutical Formulations Using Ninhydrin and Ascorbic Acid
}

\author{
Nafisur Rahman*, Manisha Singh and Md. Nasrul Hoda \\ Department of Chemistry, Aligarh Muslim University, Aligarh-202002 (U.P.) India
}

\begin{abstract}
Dois métodos espectrofotométricos, simples e sensíveis, são descritos para a determinação de lisinoprila pura e em preparações farmacêutica. O primeiro método é baseado na reação da droga com nihidrina, no solvente $\mathrm{N}, \mathrm{N}$-dimetilformamida (DMF) a temperatura ambiente, a qual é acompanhada espectrofotometricamente pela medida do aumento da absorbância a $595 \mathrm{~nm}$, em função do tempo. As técnicas de medida da velocidade inicial, da determinação da constante de velocidade e de medida em tempo fixo (10 min) foram adotadas na construção das curvas de calibração, para a determinação da concentração da droga. Os métodos de velocidade inicial e da medida em tempo fixo mostraram uma resposta linear no intervalo de concentração $10-50 \mu \mathrm{g} \mathrm{mL}^{-1}$, enquanto o método de constante de velocidade tem resposta linear no intervalo $10-40 \mu \mathrm{g} \mathrm{mL}^{-1}$. No segundo método, a droga reage com ácido ascórbico em solução de DMF, resultando num produto colorido com máximo de absorbância a $530 \mathrm{~nm}$. A lei de Beer é obedecida no intervalo de concentração 5-50 $\mu \mathrm{g} \mathrm{mL} \mathrm{mL}^{-1}$ de linisoprila, com absortividade molar de $4,548 \times 10^{3} \mathrm{~L} \mathrm{~mol}^{-1} \mathrm{~cm}^{-1}$. As variáveis que afetam o desenvolvimento da cor foram otimizadas, e o método foi validado estatisticamente e por estudos de recuperação. O método proposto foi usado com sucesso na determinação de lisinoprila em comprimidos comerciais.
\end{abstract}

Two simple and sensitive spectrophotometric methods are described for the determination of lisinopril in pure form and pharmaceutical preparations. The first method is based on the reaction of the drug with ninhydrin in N,N'-dimethylformamide (DMF) medium at room temperature which is followed spectrophotometrically by measuring the increase in absorbance at $595 \mathrm{~nm}$ as a function of time. The initial-rate, rate-constant and fixed-time (at 10 minutes) procedures were used for constructing the calibration graphs to determine the concentration of the drug. The initial-rate and fixed-time procedures showed a linear response over the concentration range $10-50 \mu \mathrm{g} \mathrm{mL}^{-1}$ whereas rate-constant procedure was applicable in the range $10-40 \mu \mathrm{g} \mathrm{mL}^{-1}$. In the second method, the drug reacts with ascorbic acid in DMF medium resulting in the formation of a coloured product, which absorbed maximally at $530 \mathrm{~nm}$. Beer's law is obeyed in the concentration $5-50 \mu \mathrm{g} \mathrm{mL}^{-1}$ of lisinopril with molar absorptivity of $4.548 \times 10^{3} \mathrm{~L} \mathrm{~mol}^{-1} \mathrm{~cm}^{-1}$. The variables affecting the development of the colour are optimized and the developed methods are validated statistically and through recovery studies. The proposed methods have been successfully applied to the determination of lisinopril in commercial tablets.

Keyword: lisinopril, ninhydrin, ascorbic acid, dimethylformamide

\section{Introduction}

Lisinopril, 1-[N-[(S)-1-carboxy-3-phenylpropyl]-L-lysyl]L-proline dihydrate, is an angiotensin converting enzyme (ACE) inhibitor. It is used in the treatment of hypertension and heart failure. The increasing use of this recently introduced drug, which is highly susceptible to the acidic degradation, needs simple, sensitive and selective method for the routine analysis in pharmaceutical formulations.

Certain successful attempts have been made for the determination of lisinopril using different analytical

* e-mail: cht17nr_amu@yahoo.com techniques. The generally used analytical techniques are liquid chromatography, ${ }^{1}$ HPTLC, ${ }^{2}$ polarography, ${ }^{3}$ capillary electrophoresis, ${ }^{4,5}$ chemiluminescence, ${ }^{6}$ HPLC, ${ }^{7,8}$ and potentiometric titration..$^{9}$ Of course, the above mentioned techniques are sensitive but expensive. Spectrophotometry is the technique of choice even today due to its inherent simplicity. It is frequently used in the laboratories of the developing countries to overcome versatile analytical problems. In the literature, few spectrophotometric methods have been reported for its determination. Lisinopril has been determined in the visible region based on the reaction 
with sodium hypochlorite and phenylhydrazine, ${ }^{2}$ chloranil, ${ }^{10}$ dichlone, ${ }^{10}$ acetylacetone and formaldehyde, ${ }^{10}$ 1,2-napthoquinone-4-sulphonic acid, ${ }^{11}$ 2,4,6-trinitro-benzoic acid, ${ }^{12}$ 2,4dinitroflurobenzene ${ }^{13}$ and 7-chloro-4-nitrobenzo-2oxa-1, 3-diazole. ${ }^{14}$ Panzade and co-workers ${ }^{15}$ have reported a UV spectrophotometric method for the quantification of lisinopril at $205 \mathrm{~nm}$. Beer's law was obeyed in the concentration range of $3-30 \mu \mathrm{g} \mathrm{mL}^{-1}$. The literature ${ }^{16}$ revealed that the reaction of ninhydrin has been used earlier for the direct spectro-photometric determination of lisinopril after heating on a water bath for 10 minutes. A derivative spectropho-tometric procedure ${ }^{17}$ for the simultaneous determination of amlodipine and lisinopril was developed. In this method, the drug was extracted in $0.1 \mathrm{~mol} \mathrm{~L}^{-1} \mathrm{HCl}$ and zero crossing point technique was employed to determine the amounts of individual drugs in the combined preparations. Jain and coworkers ${ }^{18}$ have discussed two procedures for simultaneous determination of amlodipine besylate and lisinopril in tablets. The first method was based on the development of two equations for area calculation of curve at two wavelength regions. The second method employed multicomponent mode of analysis over the range 300$190 \mathrm{~nm}$ using four sampling points 300, 271, 242 and $213 \mathrm{~nm}$. The lisinopril was also determined in pharmaceutical formulations using ratio spectra derivative spectrophotometry ${ }^{19}$ and derivative spectrophotometry. ${ }^{2,3,19,20}$ The literature is still poor with regard to the kinetic spectrophotometric method of analysis. As far as our knowledge is concerned, no kinetic spectrophotometric method is reported for the assay of lisinopril. The following specific advantages associated with the kinetic method ${ }^{21}$ can be expected: (i) method is considerably simpler and faster since some of the experimental steps (i.e., heating on water bath and cooling) prior to absorbance measurements have been eliminated; (ii) more selectivity since it involves the measure of evolution of absorbance as a function of reaction time instead of the measure of a concrete absorbance value; (iii) the coloured and/or turbidity background of the samples most likely does not interfere with the determination; (iv) other active compounds present in dosage form may not interfere if they resist optimized chemical reaction conditions of the proposed kinetic method.

The kinetic approach for determining lisinopril in commercial dosage form using ninhydrin as a reagent reduces the time of analysis as it does not required heating and cooling of the reaction mixture.
Ninhydrin is a well-established reagent for the determination of certain amines, amino acids and thiophenes. ${ }^{22}$ It has been extensively used in the determination of the compounds of pharmaceutical importance and in the kinetic studies. ${ }^{23-25}$ Ascorbic acid has been used $^{26}$ as a sensitive reagent for the specific determination of aliphatic amines in N,N'-dimethylformamide (DMF) medium without elucidating the mechanism of the reaction. In this laboratory, we have used ascorbic acid as a reagent for the determination of a pharmaceutical possessing aliphatic amino group and proposed a reaction mechanism after an appropriate study. ${ }^{27}$

In the present manuscript, two sensitive spectrophotometric methods for the determination of lisinopril in DMF medium have been described. The first method is based on the reaction of lisinopril with ninhydrin at room temperature for which a kinetic approach has been adopted. The second method is based on the reaction of lisinopril with ascorbic acid. The proposed methods have been successfully applied to the determination of lisinopril in pharmaceutical formulations.

\section{Experimental}

\section{Apparatus}

Bausch and Lomb Spectronic 20D $\mathrm{D}^{+}$spectrophotometer (Milton Roy, USA) was used for measurement.

\section{Reagents and materials}

DMF (spectroscopy grade) and ascorbic acid (ARgrade) were obtained from S.D. Fine Chemicals, India. Ninhydrin was purchased from Merck-Schuchardt, Germany. The $0.1 \%$ solution of lisinopril was prepared by dissolving $100 \mathrm{mg}$ of pure lisinopril (M/s. Zydus Cadila Healthcare Limited, India) in $10 \mathrm{~mL}$ of doubly distilled water into a $100 \mathrm{~mL}$ volumetric flask and finally made up to the mark with DMF. Further dilutions were made according to the need using 9:1 mixture of DMF:Water. The $2 \%$ ninhydrin solution was prepared in DMF. Ascorbic acid solution (0.2\%) was prepared by dissolving $100 \mathrm{mg}$ in $0.5 \mathrm{~mL}$ of distilled water, in a 50 $\mathrm{mL}$ standard flask and completing the volume with DMF.

\section{Preparation of the acid induced degradation product}

Lisinopril dihydrate $(50 \mathrm{mg})$ was transferred into a conical flask and then $50 \mathrm{~mL}$ of $50 \% \mathrm{H}_{2} \mathrm{SO}_{4}$ was added. It was refluxed for $2 \mathrm{~h}$ at $100^{\circ} \mathrm{C}$. After cooling, the solution 
was neutralized with calcium carbonate and filtered. The filtrate was evaporated to dryness and the residue was tested for complete degradation using TLC plate coated with silica gel-G and chloroform - ethyl acetate - acetic acid $(10: 3: 2 \mathrm{v} / \mathrm{v})$ as mobile phase. A single spot was observed at $R_{\mathrm{f}}=0.17$ whereas no spot was detected at $\mathrm{R}_{\mathrm{f}}=0.31$ corresponding to lisinopril dihydrate.

\section{Recommended procedures}

Ninhydrin method. Aliquots of $0.05 \%$ lisinopril corresponding to 50-250 $\mu \mathrm{g}$ were transferred into a series of $5 \mathrm{~mL}$ standard volumetric flasks. To each flask, $1.7 \mathrm{~mL}$ of $2 \%$ ninhydrin solution was added and diluted to volume with DMF. The contents of the mixture were mixed well and increase in absorbance at $595 \mathrm{~nm}$ was recorded as a function of time against the reagent blank at room temperature. The initial rate of reaction at different concentration was calculated from the initial slope of absorbance time curve. The calibration curves were constructed by plotting $(i)$ logarithm of initial-rate of reaction versus logarithm of molar concentration, (ii) rate-constant versus final concentration, and (iii) absorbance measured at a fixed-time of 10 minutes versus final concentration of lisinopril.

Ascorbic acid method. Into a series of boiling tubes, increasing volumes of $0.05 \%$ lisinopril were quantitatively transferred so as to contain the drug within the concentration range of 5-50 $\mu \mathrm{g} \mathrm{mL}^{-1}$. To each tube, $2 \mathrm{~mL}$ of ascorbic acid solution (0.2\%) was added and volumes were maintained to $5 \mathrm{~mL}$ with DMF. The solutions were heated on a water bath at $100 \pm 1{ }^{\circ} \mathrm{C}$ for 15 minutes. The solutions were cooled at room temperature. The contents of each tube were transferred to a $10 \mathrm{~mL}$ standard flasks and completed to volume with DMF. The absorbances were measured at $530 \mathrm{~nm}$ against the reagent blank prepared simultaneously within the stability period of $3 \mathrm{~h}$. The calibration curve was constructed by plotting the absorbance versus final concentration of the lisinopril. The content of the drug was computed either from calibration curve or regression equation.

Analysis of pharmaceutical formulations. 10 tablets equivalent to $100 \mathrm{mg}$ of the lisinopril were powdered and transferred into a small flask with $50 \mathrm{~mL}$ methanol and stirred. The extract was filtered into $100 \mathrm{~mL}$ volumetric flask and diluted to volume with methanol. The filtrate was evaporated to dryness. The residue was dissolved with $10 \mathrm{~mL}$ distilled water and diluted to 100 $\mathrm{mL}$ with DMF. The assay of lisinopril was completed following the recommended procedures.

\section{Results and Discussion}

It has been suggested ${ }^{28}$ that ninhydrin was converted to o-carboxyphenylglyoxal in alkaline medium which would reduce ninhydrin to 2-hydroxyindan-1,3-dione. In the present study, it combines with $-\mathrm{NH}_{2}$ group of lisinopril to form amino derivative, which further undergoes condensation with ninhydrin to give diketohydrindylindene-diketohydrindamine (Figure 1).

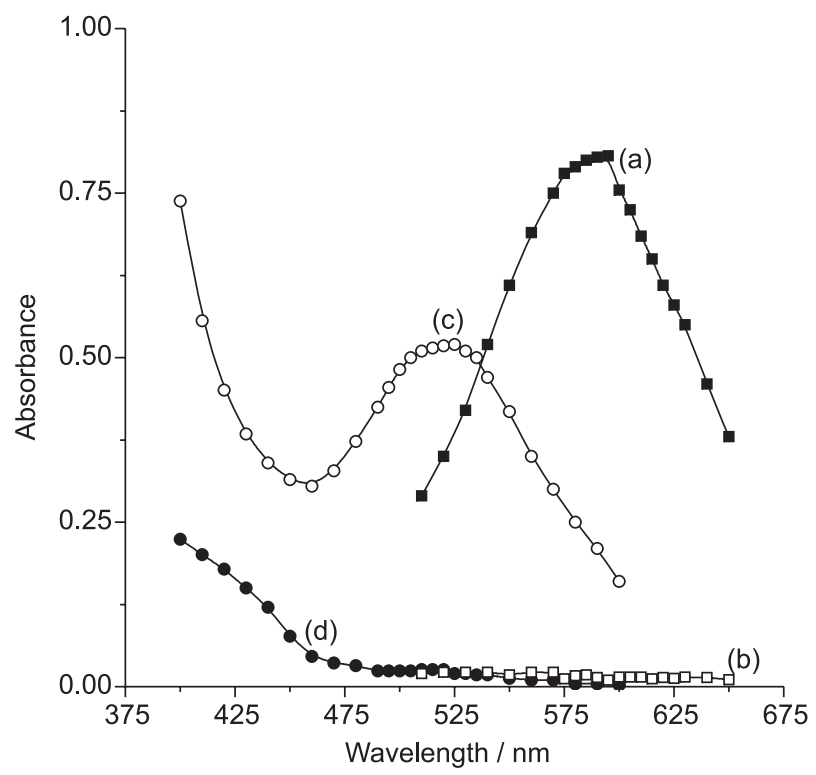

Figure 1. Absorption spectra of reaction products (a, lisinopril ninhydrin and c, lisinopril - ascorbic acid) and their reagent blanks (b and d, respectively).

Lisinopril, as a primary amine, reacts with ascorbic acid in DMF medium to produce a coloured product, which absorbed maximally at $530 \mathrm{~nm}$ (Figure 1). Under the specified experimental conditions, ascorbic acid undergoes oxidation resulting in the formation of dehydroascorbic acid. ${ }^{29}$ The carbonyl group of dehydroascorbate reacts with $-\mathrm{NH}_{2}$ group of lisinopril to form a purple coloured condensation product. By analogy to previous report, ${ }^{27}$ the reaction is proposed to proceed as shown in Scheme 1.

\section{Optimization of reaction variables}

The reaction between lisinopril and ninhydrin in DMF resulted in the formation of diketohydrindylindenediketohydrindamine. At room temperature $\left(\sim 25^{\circ} \mathrm{C}\right)$, the intensity of colour increased with time and became stable after 45 minutes of reagent mixing. The effect of ninhydrin concentration on reaction rate was investigated using 0.8$2.4 \mathrm{~mL}$ of $2.0 \%$ ninhydrin. It was found that increasing the volume of $2.0 \%$ ninhydrin solution would increase the 
<smiles>O=C1OC(C(O)CO)C(O)=C1O</smiles><smiles>O=C1OC(C(O)CO)C(=O)C1=O</smiles><smiles>NCCCCC(NC(CCc1ccccc1)C(=O)O)C(=O)N1CCCC1C(=O)O</smiles>
$+$<smiles>O=C1OC(C(O)CO)C(=O)C1=O</smiles><smiles></smiles><smiles>CC(CCc1ccccc1)C(=O)O</smiles><smiles>NC(CCCCN=C1C(=NCCCCC(NC(CCc2ccccc2)C(=O)O)C(=O)N2CCCC2C(=O)O)C(=O)OC1C(O)CO)C(=O)N1CCCC1C(=O)O</smiles>

Scheme 1.

absorbance of the reaction product up to $1.5 \mathrm{~mL}$, after which further increase in the volume of ninhydrin resulted in no change in the absorbance of reaction product. Thus, $1.7 \mathrm{~mL}$ of $2.0 \%$ ninhydrin was adopted as the most suitable volume for maximum absorbance.

The reaction of lisinopril and ascorbic acid in DMF medium involves two variables i.e. heating time and concentration of ascorbic acid. To study the effect of heating time for ascorbic acid method, $500 \mu \mathrm{g}$ of lisinorpil was mixed with $2.0 \mathrm{~mL}$ of $0.2 \%$ ascorbic acid in a boiling tube and heated on a water bath at $100 \pm 1^{\circ} \mathrm{C}$. The absorbance was measured at $530 \mathrm{~nm}$ as a function of time. It was observed (Figure 2) that the absorbance remained constant between 14 and 21 minutes of heating. Thus, 16 minutes of heating time was selected as an optimum value. The influence of volume of $0.2 \%$ ascorbic acid was critically examined. It is evident from Figure 2 that the maximum absorbance was obtained with $1.5 \mathrm{~mL}$ and above this volume the absorbance remained unaffected. Therefore, $2 \mathrm{~mL}$ of $0.2 \%$ ascorbic acid was used throughout the experiment.

The stoichiometric ratio between ninhydrin and lisinopril was established by the limiting logarithmic

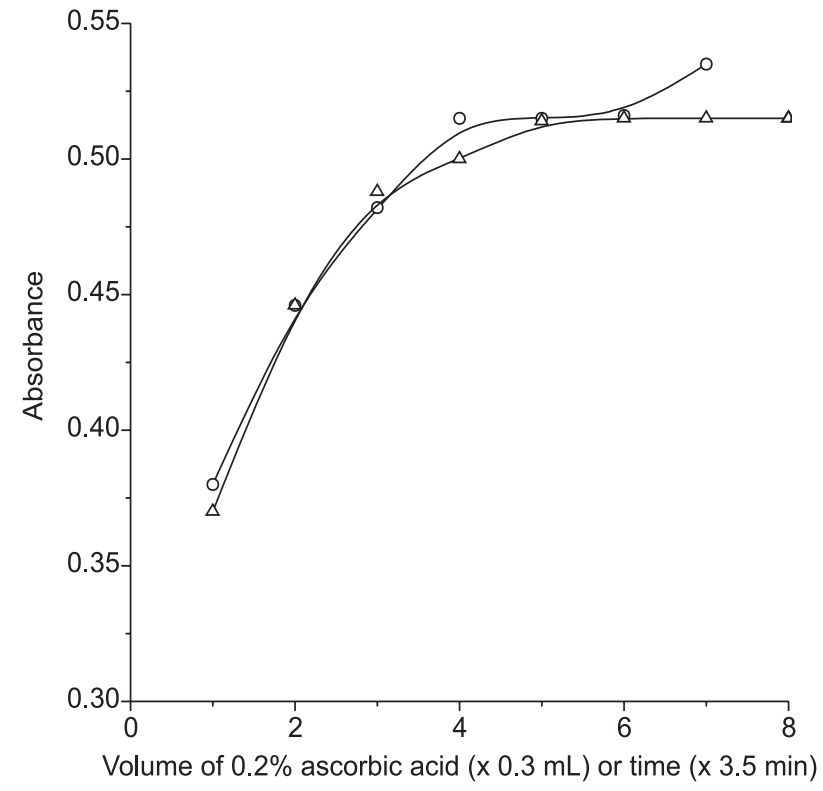

Figure 2. Effect of heating time $(O)$ and volume of $0.2 \%$ ascorbic acid $(\triangle)$ on the lisinopril - ascorbic acid reaction.

method using two sets of the experiments. In the first set, lisinopril concentration was varied keeping ninhydrin concentration constant and vice versa in the second set of experiment. The logarithms of the absorbance thus obtained were plotted against the respective logarithms of the molar concentrations. The slopes of the two straight lines were obtained to be unity in each case, which indicated the combining molar ratio between lisinopril and ninhydrin is $1: 1$ (Figure 3 ).

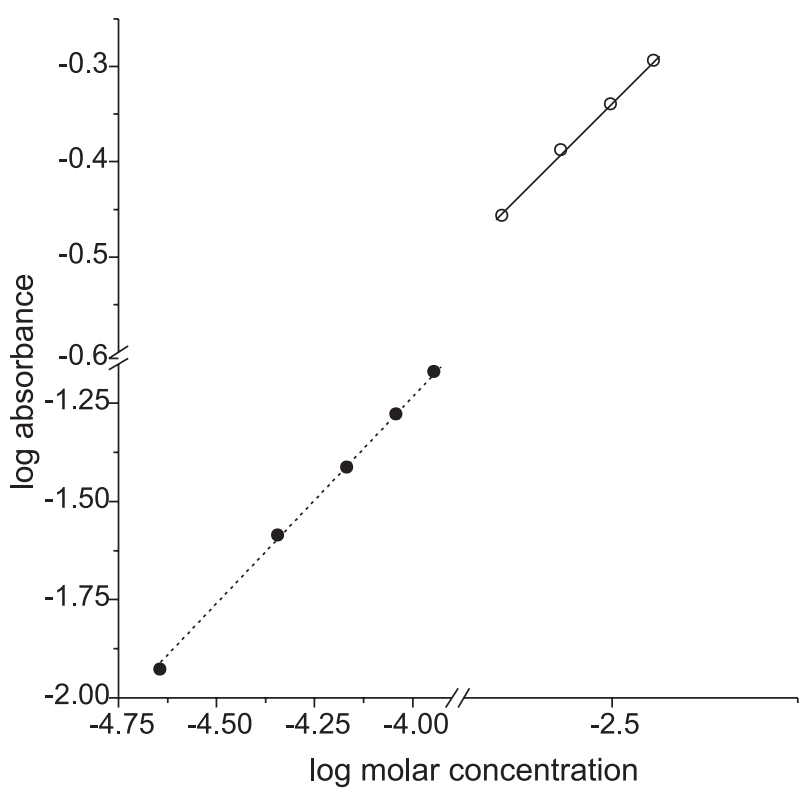

Figure 3. Determination of the stoichiometric ratio between lisinopril and ninhydrin by the limiting logarithmic method. (O) Constant ninhydrin concentration and variable lisinopril concentrations. ( $\mathrm{O})$ Constant lisinopril concentration and variable ninhydrin concentrations. 


\section{Kinetic study using ninhydrin}

Initial-rate method. The initial rates of the reaction were determined from the measurements of the slopes of the initial tangents to the absorbance - time curves (Figure 4). The order with respect to lisinopril was ascertained by studying the reaction at different concentrations of lisinopril keeping a constant concentration of ninhydrin. For each run, a plot of $\log \mathrm{A}_{\infty} / \mathrm{A}_{\infty}-\mathrm{A}_{\mathrm{t}}$ versus time is a straight line confirming the first order reaction. The first order rate constants were evaluated from the slopes of the plots of $\log \mathrm{A}_{\infty} / \mathrm{A}_{\infty}-\mathrm{A}_{t}$ versus time. All subsequent investigations were also performed with different concentrations of ninhydrin with a fixed concentration of lisinopril. The plot of $\log A_{\infty} / A_{\infty}-A_{t}$

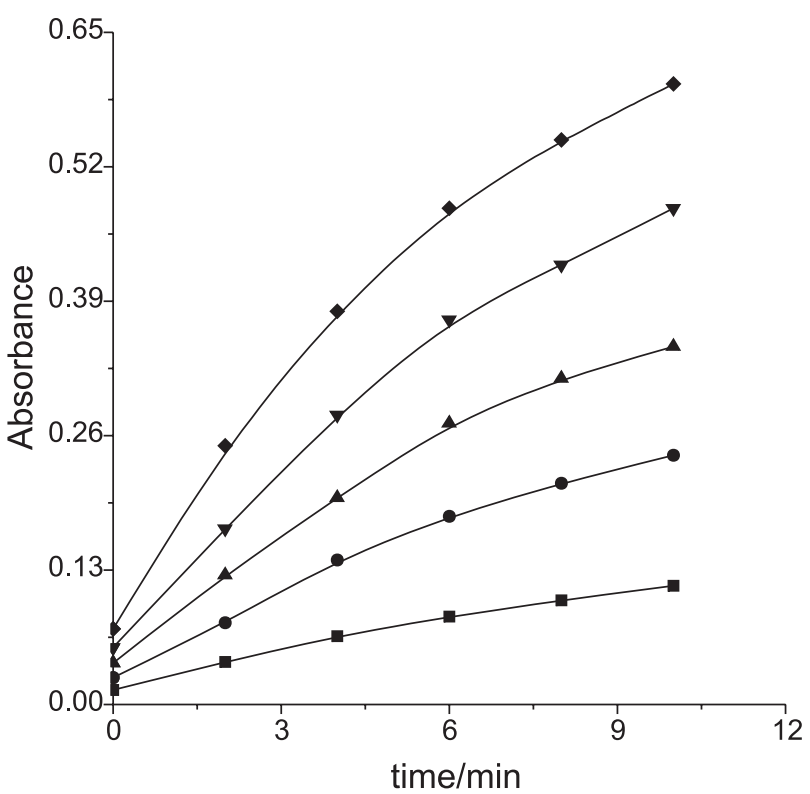

Figure 4. Absorbance-time curve for the varying concentrations of lisinopril and fixed concentration of ninhydrin $\left(3.82 \times 10^{-3} \mathrm{~mol} \mathrm{~L}^{-1}\right)$. () $2.26 \times 10^{-5} \mathrm{~mol} \mathrm{~L}^{-1}$; (O) $4.53 \times 10^{-5} \mathrm{~mol} \mathrm{~L}^{-1}$; (A) $6.80 \times 10^{-5} \mathrm{~mol}$ $\mathrm{L}^{-1} ;(1 / 4 \%) 9.06 \times 10^{-5} \mathrm{~mol} \mathrm{~L}^{-1} ;(\boldsymbol{\nabla}) 11.33 \times 10^{-5} \mathrm{~mol} \mathrm{~L}^{-1}$

Table 1. Statistical data of the proposed procedures versus time also indicated a first order kinetics with respect to ninhydrin concentration.

Under the optimized experimental parameters, ninhydrin concentration was used in excess in order to work out pseudo-first order condition. Therefore, the initial rate of reaction under pseudo-first order conditions would obey the following equation:

Rate $=\Delta \mathrm{A} / \Delta \mathrm{t}=\mathrm{k}^{\prime} \mathrm{C}^{\mathrm{n}}$

Where, $\mathrm{k}^{\prime}$ is the pseudo-first order rate constant, $\mathrm{C}$ is the concentration of lisinopril, $\mathrm{n}$ is the order of reaction. The above equation may be written in logarithmic form as

$\log$ rate $=\log \mathrm{k}^{\prime}+\mathrm{n} \log \mathrm{C}$

The slope, intercept and correlation coefficient were evaluated by linear regression analysis of calibration data (Table 1). The regression of $\log$ rate versus $\log \mathrm{C}$ gave a linear regression equation,

$\log$ rate $=3.078+1.076 \log \mathrm{C}$

The value of $\mathrm{n}$ in the regression equation also indicated the first order reaction with respect to lisinopril concentration. The calibration curve constructed by plotting log rate versus log molar concentration of lisinopril showed a linear relationship over the concentration range of 10-50 $\mu \mathrm{g} \mathrm{mL} \mathrm{m}^{-1}$.

Rate-constant method. Under pseudo-first order condition, the rate constants corresponding to different concentrations of lisinopril were calculated from the slopes of $\log \mathrm{A}_{\infty} / \mathrm{A}_{\infty}-\mathrm{A}_{\mathrm{t}}$ versus time and are summarized in Table 2 . The calibration graph was constructed by plotting rate constant against the lisinopril concentration, which showed a linear response over the concentration range of 10-40 $\mu \mathrm{g} \mathrm{mL}^{-1}$. The regression equation, correlation coefficient, detection limit, variance and standard

\begin{tabular}{|c|c|c|c|}
\hline \multirow[t]{2}{*}{ Parameter } & \multicolumn{2}{|c|}{ Kinetic methods using ninhydrin } & \multirow[t]{2}{*}{ Ascorbic acid method } \\
\hline & Initial rate & Rate constant & \\
\hline Linear dynamic range $\left(\mu \mathrm{g} \mathrm{mL}^{-1}\right)$ & $10-50$ & $10-40$ & $5-50$ \\
\hline \multicolumn{4}{|l|}{ Regression data: } \\
\hline Intercept $(a)$ & 3.078 & $8.563 \times 10^{-2}$ & $1.062 \times 10^{-3}$ \\
\hline $\mathrm{Sa}$ & 0.146 & $1.414 \times 10^{-3}$ & $7.828 \times 10^{-2}$ \\
\hline$\pm \mathrm{tSa}$ & 0.312 & $3.041 \times 10^{-3}$ & 0.152 \\
\hline Slope $(b)$ & 1.076 & $1.083 \times 10^{-3}$ & $1.023 \times 10^{-2}$ \\
\hline $\mathrm{S}_{\mathrm{b}}$ & 0.292 & $6.334 \times 10^{-5}$ & $1.696 \times 10^{-3}$ \\
\hline$\pm \mathrm{tS}_{\mathrm{b}}$ & 0.622 & $1.352 \times 10^{-4}$ & $3.295 \times 10^{-3}$ \\
\hline Correlation coefficient $(r)$ & 0.9978 & 0.9972 & 0.9992 \\
\hline Variance $\left(S_{o}^{2}\right)$ & $7.312 \times 10^{-5}$ & $1.648 \times 10^{-6}$ & $7.234 \times 10^{-5}$ \\
\hline Limit of detection $\left(\mu \mathrm{g} \mathrm{mL}^{-1}\right)$ & 0.118 & 2.839 & 0.349 \\
\hline SAE & $3.491 \times 10^{-3}$ & $5.724 \times 10^{-4}$ & $3.472 \times 10^{-3}$ \\
\hline
\end{tabular}


Table 2. Values of rate constant (k) calculated from slopes of $\log$ $\mathrm{A} \infty / \mathrm{A} \infty-\mathrm{A}_{\mathrm{t}}$ versus time graphs at $595 \mathrm{~nm}$

\begin{tabular}{cc}
\hline $\mathrm{k}\left(\mathrm{min}^{-1}\right)$ & Concentration of lisinopril $\left(\mu \mathrm{g} \mathrm{mL} \mathrm{mL}^{-1}\right)$ \\
\hline $9.576 \times 10^{-2}$ & 10 \\
$10.863 \times 10^{-2}$ & 20 \\
$11.708 \times 10^{-2}$ & 30 \\
$12.888 \times 10^{-2}$ & 40 \\
\hline
\end{tabular}

analytical error are presented in Table 1.

Fixed time method. At a preselected fixed time, the absorbance was measured at $595 \mathrm{~nm}$ against reagent blank. The calibration graphs of absorbance versus initial concentration of lisinopril were established at fixed time of 4, 6, 8, 10 and 12 minutes. Under the established working condition, regression equations were developed and important analytical parameters have been calculated (Table 3). It is evident from Table 3 that the most acceptable values of correlation coefficient, detection limit and variance were obtained at a fixed time of 10 minutes. Therefore, the fixed time of 10 minutes was utilized for assay of lisinopril concentration.

Ascorbic acid method: Under the optimum experimental conditions, the linear calibration graph was obtained over the concentration range $5-50 \mu \mathrm{g} \mathrm{mL}^{-1}$. The calibration data were fitted by least square treatment and the corresponding calibration equation along with the relevant analytical parameters are summarized in Table 1.

Under the optimum experimental conditions, the values of slopes of the regression equations of the proposed methods indicate good sensitivity. The small values of the variance speak about the negligible scattering of the calibration data points around the line of regressions for all the proposed procedures. The high values of correlation coefficients obtained for regression equations exhibit good linearity of the methods. The significance of correlation coefficients was evaluated by calculating the t-values using the following formula. ${ }^{30}$

$t=\frac{|r| \sqrt{n-2}}{\sqrt{1-r^{2}}}$

The calculated values were found to be 26.07, 23.10, 70.68 and 55.87 for initial-rate, rate-constant, fixed-time and ascorbic acid methods, respectively. Thus, it can be concluded that there is significant relationship between the concentration of lisinopril and the variables used in the development of regression equations.

To check the precision as well as accuracy of the proposed methods, independent repeatability studies were performed with six repetitions for each method. The results are summarized in Table 4. The obtained data show that the methods are reproducible as well as accurate.

Table 3. Calibration equations, precision and accuracy at different fixed times for lisinopril concentrations in the range of $10-50 \mu \mathrm{g} \mathrm{mL}^{-1}$

\begin{tabular}{|c|c|c|c|c|c|}
\hline \multirow[t]{2}{*}{ Parameter } & \multicolumn{5}{|c|}{ Fixed time methods } \\
\hline & $4 \mathrm{~min}$ & $6 \mathrm{~min}$ & $8 \mathrm{~min}$ & $10 \mathrm{~min}$ & $12 \min$ \\
\hline Calibration & $\mathrm{A}=5.09 \times 10^{-3}$ & $A=7.68 \times 10^{-3}$ & $\mathrm{~A}=9.8 \times 10^{-3}$ & $\mathrm{~A}=1.10 \times 10^{-2}$ & $\mathrm{~A}=1.21 \times 10^{-2}$ \\
\hline $\mathrm{Eq}^{\mathrm{n}}$ & C- $-1.97 \times 10^{-2}$ & C- $1.72 \times 10^{-2}$ & C- $1.58 \times 10^{-2}$ & C- $1.02 \times 10^{-2}$ & $C-6.8 \times 10^{-3}$ \\
\hline Correlation & & & & & \\
\hline coefficient & $r=0.9887$ & $\mathrm{r}=0.9958$ & $\mathrm{r}=0.9995$ & $r=0.9996$ & $\mathrm{r}=0.9995$ \\
\hline$\pm \mathrm{tS}_{\mathrm{a}}$ & $3.0 \times 10^{-2}$ & $2.76 \times 10^{-2}$ & $1.24 \times 10^{-2}$ & $1.19 \times 10^{-2}$ & $1.50 \times 10^{-2}$ \\
\hline$\pm \mathrm{tS}_{\mathrm{b}}$ & $9.49 \times 10^{-4}$ & $8.72 \times 10^{-4}$ & $3.91 \times 10^{-4}$ & $3.75 \times 10^{-4}$ & $4.75 \times 10^{-4}$ \\
\hline $\begin{array}{l}\text { Molar absorptivity } \\
\left(1 \mathrm{~mol}^{-1} \mathrm{~cm}^{-1}\right)\end{array}$ & $1.876 \times 10^{3}$ & $3.090 \times 10^{3}$ & $4.01 \times 10^{3}$ & $4.70 \times 10^{3}$ & $5.30 \times 10^{3}$ \\
\hline $\begin{array}{l}\text { Detection limit } \\
\left(\mu \mathrm{g} \mathrm{mL}^{-1}\right)\end{array}$ & 5.63 & 3.43 & 3.81 & 1.03 & 1.38 \\
\hline Variance & $1.98 \times 10^{-4}$ & $1.68 \times 10^{-4}$ & $3.36 \times 10^{-5}$ & $3.09 \times 10^{-5}$ & $6.59 \times 10^{-5}$ \\
\hline S.D. & $1.41 \times 10^{-2}$ & $1.29 \times 10^{-2}$ & $5.8 \times 10^{-3}$ & $5.56 \times 10^{-3}$ & $8.12 \times 10^{-3}$ \\
\hline SAE & 0.0063 & 0.0058 & 0.0023 & 0.0025 & 0.0036 \\
\hline
\end{tabular}

$\pm \mathrm{tS}_{\mathrm{a}}=$ Confidence limit for intercept. $\pm \mathrm{tS}_{\mathrm{b}}=$ Confidence limit for slope. SAE = Standard analytical error.

Table 4. Test of accuracy and precision of the proposed procedures

\begin{tabular}{|c|c|c|c|c|c|}
\hline Methods & Amount taken $\left(\mu \mathrm{g} \mathrm{mL}^{-1}\right)$ & Amount found $\left(\mu \mathrm{g} \mathrm{mL}^{-1}\right) \pm$ S.D. ${ }^{a}$ & Accuracy $\pm \operatorname{RSD}(\%)^{a}$ & $S A E^{a, b}$ & $p$-value \\
\hline \multicolumn{6}{|l|}{ Kinetic method } \\
\hline Initial rate & 30 & $30.52 \pm 0.53$ & $101.74 \pm 1.74$ & 0.217 & 0.558 \\
\hline Rate constant & 30 & $30.20 \pm 0.37$ & $100.68 \pm 1.23$ & 0.151 & 0.322 \\
\hline Fixed time & 30 & $30.22 \pm 0.35$ & $100.74 \pm 1.16$ & 0.143 & 0.305 \\
\hline Ascorbic acid & 25 & $24.95 \pm 0.18$ & $99.78 \pm 0.74$ & 0.075 & 0.193 \\
\hline
\end{tabular}

${ }^{a}$ Six independent analyses; ${ }^{b} S A E$, Standard analytical error. $t$-value $(\mathrm{Df}=5)$ is $2.015 .{ }^{32}$ 
The performance of the proposed methods was compared with that of other existing UV-visible spectrophotometric methods (Table 5). It is apparent from table that the values of molar absorptivity of the proposed methods (ascorbic acid and fixed time methods) are greater than that of other methods except the methods using chloranil and acetylacetone but these methods are more tedious to perform. The values of LOD and LOQ of initial rate method are smaller than that of the other existing spectrophotometric methods whereas ascorbic acid method has somewhat higher LOD and LOQ values than that of the method using 7-chloro-4-nitrobenzo-2-oxa-1,3diazole but it requires longer heating time for reaction to occur. The proposed ninhydrin method is much superior than the other reported method ${ }^{16}$ as its does not require heating in a boiling water bath. Thus the methods are found to be simple and can compete with the existing spectrophotometric methods in determining the drug in lower concentrations.

The reliability of the proposed methods was checked by the standard addition method. The results (Table 6) show that the mean recoveries were found in the range $99.25-101.29$ with RSD $\leq 1.5 \%, 99.05-99.59 \%$ with $\mathrm{RSD} \leq 1.4 \%, 99.12-99.98 \%$ with $\mathrm{RSD} \leq 0.5 \%$ and 99.66 -100.80 with RSD $\leq 0.7 \%$. Common excipients in tablets such as talc, lactose, starch or magnesium stearate did not interfere with the assay.

The analysis of lisinopril in commercial tablets was performed using the proposed procedures and reference method. ${ }^{10}$ The results obtained were compared statistically by the student's $t$-test and variance ratio $F$-test (Table 7). The experimental $t$ - and $F$ - values did not exceed the theoretical ones at 95\% confidence level, indicating the absence of any significant difference between the compared methods. The interval hypothesis test ${ }^{31}$ have also been performed to compare the results of the proposed procedures (initial-rate, rate-constant, fixed-time or ascorbic acid) with those of reference method at 95\% confidence level. In pharmaceutical analysis, a bias of $\pm 2 \%$ is permissible. The results show that the data are within the limit of the interval at $95 \%$ confidence level.

As far as the selectivity of the method is concerned, the kinetic approach based on the reaction of lisinopril -

Table 5. Comparison of the proposed methods with existing spectrophotometric methods for the assay of lisinopril in pharmaceutical formulations

\begin{tabular}{|c|c|c|c|c|c|c|c|c|}
\hline S.No & Reagents & $\lambda \max$ & $\begin{array}{l}\text { Linear Dynamic } \\
\text { Range } \mu \mathrm{g} \mathrm{mL}^{-1}\end{array}$ & Reaction time & $\begin{array}{l}\text { Molar absorptivity } \\
\text { (ع) } \mathrm{Lmol}^{-1} \mathrm{~cm}^{-1}\end{array}$ & LOD & LOQ & References \\
\hline 1. & Chloranil & 346 & $4-20$ & $45 \min$ at $60^{\circ} \mathrm{C}$ & $2.07 \times 10^{4}$ & - & - & 10 \\
\hline 2. & Dichlone & 580 & $40-120$ & $10 \mathrm{~min}$ at $\mathrm{rt}$ & $2.6 \times 10^{3}$ & - & - & 10 \\
\hline \multirow[t]{2}{*}{3.} & Acetylacetone + & & & & & & & \\
\hline & Formaldehyde & 356 & $6-42$ & $10 \mathrm{~min}$ at $100^{\circ} \mathrm{C}$ & $9.62 \times 10^{3}$ & - & - & 10 \\
\hline 4. & 2,4- dinitrofluorobenzene & 400 & $4.04-20.20$ & $30 \mathrm{~min}$ at $80^{\circ} \mathrm{C}$ & - & 1.16 & 3.87 & 13 \\
\hline 5. & Phenylhydraizine & 362 & $40-200$ & $20 \mathrm{~min}$ at $85^{\circ} \mathrm{C}$ & - & - & - & 2 \\
\hline \multirow[t]{2}{*}{6.} & 7-chloro-4-nitrobenzo- & & & & & & & \\
\hline & 2-oxa-1, 3-diazole & 470 & $2-20$ & $30 \mathrm{~min}$ at $70^{\circ} \mathrm{C}$ & - & 0.27 & 0.891 & 14 \\
\hline 7. & Ninhydrin & 410 & $10-40$ & $10 \mathrm{~min}$ at $100^{\circ} \mathrm{C}$ & $1.845 \times 10^{3}$ & - & - & 16 \\
\hline $\begin{array}{l}8 . \\
9 .\end{array}$ & $\begin{array}{l}\text { Ascorbic acid } \\
\text { Ninhydin }\end{array}$ & 530 & $5-50$ & $15 \mathrm{~min}$ at $100^{\circ} \mathrm{C}$ & $4.548 \times 10^{3}$ & 0.349 & 1.152 & This work \\
\hline a) & Initial rate method & 595 & $10-50$ & $\begin{array}{l}\text { Immediately after } \\
\text { mixing the reagent at } \mathrm{r}\end{array}$ & $\mathrm{rt}$ & 0.118 & 0.389 & This work \\
\hline b) & Rate constant method & 595 & $10-40$ & - do- & - & 2.839 & 9.369 & This work \\
\hline c) & Fixed time method & 595 & $10-50$ & $10 \mathrm{~min}$ at $\mathrm{rt}$ & $4.70 \times 10^{3}$ & 1.03 & 3.399 & This work \\
\hline
\end{tabular}

$\mathrm{rt}=$ Room temperature.

Table 6. Determination of lisinopril in pharmaceutical formulations by standard addition method

\begin{tabular}{|c|c|c|c|c|c|c|c|c|c|c|c|c|}
\hline \multirow{4}{*}{$\begin{array}{l}\text { Pharmaceutical } \\
\text { formulations }\end{array}$} & \multicolumn{9}{|c|}{ Kinetic Methods using ninhydrin } & & & \\
\hline & \multicolumn{3}{|c|}{ Initial-rate } & \multicolumn{3}{|c|}{ Rate-constant } & \multicolumn{3}{|c|}{ Fixed-time } & \multicolumn{3}{|c|}{ Ascorbic acid } \\
\hline & \multicolumn{2}{|c|}{ Amount $\left(\mu \mathrm{g} \mathrm{mL}^{-1}\right)$} & \multirow{2}{*}{$\begin{array}{l}\text { Recovery } \\
\pm \operatorname{RSD}(\%)^{\mathrm{a}}\end{array}$} & \multicolumn{2}{|c|}{ Amount $\left(\mu \mathrm{g} \mathrm{mL}^{-1}\right)$} & \multirow{2}{*}{$\begin{array}{l}\text { Recovery } \\
\pm \operatorname{RSD}(\%)^{\mathrm{a}}\end{array}$} & \multicolumn{2}{|c|}{ Amount $\left(\mu \mathrm{g} \mathrm{mL}^{-1}\right)$} & \multirow{2}{*}{$\begin{array}{c}\text { Recovery } \\
\pm \operatorname{RSD}(\%)^{\mathrm{a}} \\
+ \text { added }\end{array}$} & \multicolumn{2}{|c|}{ Amount $\left(\mu \mathrm{g} \mathrm{mL}^{-1}\right)$} & \multirow{2}{*}{$\begin{array}{l}\text { Recovery } \\
\pm \mathrm{RSD}(\%)^{\mathrm{a}}\end{array}$} \\
\hline & $\begin{array}{l}\text { Taken } \\
+ \text { added }\end{array}$ & $\begin{array}{l}\text { Found } \\
\pm \mathrm{SD}^{\mathrm{a}}\end{array}$ & & $\begin{array}{c}\text { Taken } \\
+ \text { added }\end{array}$ & $\begin{array}{c}\text { Found } \\
\pm \mathrm{SD}^{\mathrm{a}}\end{array}$ & & $\begin{array}{l}\text { Taken } \\
+ \text { added }\end{array}$ & $\begin{array}{l}\text { Found } \\
\pm \mathrm{SD}^{\mathrm{a}}\end{array}$ & & $\begin{array}{l}\text { Taken } \\
\pm \mathrm{SD}^{\mathrm{a}}\end{array}$ & Found & \\
\hline \multirow[t]{2}{*}{ Linvas (Cadila) } & $20+20$ & $40.52 \pm 0.62$ & $101.29 \pm 1.54$ & $20+20$ & $39.84 \pm 0.47$ & $99.59 \pm 1.19$ & $20+20$ & $39.66 \pm 0.11$ & $99.14 \pm 0.27$ & $15+15$ & $30.24 \pm 0.18$ & $100.80 \pm 0.61$ \\
\hline & $25+25$ & $50.52 \pm 0.74$ & $101.04 \pm 1.47$ & $25+25$ & $49.52 \pm 0.37$ & $99.05 \pm 0.75$ & $25+25$ & $49.99 \pm 0.27$ & $99.98 \pm 0.55$ & $25+25$ & $50.16 \pm 0.16$ & $100.32 \pm 0.32$ \\
\hline \multirow[t]{2}{*}{ Listril (Torrent) } & $20+20$ & $39.70 \pm 0.53$ & $99.25 \pm 1.32$ & $20+20$ & $39.69 \pm 0.57$ & $99.23 \pm 1.45$ & $20+20$ & $39.64 \pm 0.11$ & $99.12 \pm 0.28$ & $15+15$ & $30.14 \pm 0.24$ & $100.47 \pm 0.79$ \\
\hline & $25+25$ & $50.17 \pm 0.65$ & $100.33 \pm 1.29$ & $25+25$ & $49.75 \pm 0.29$ & $99.50 \pm 0.59$ & $25+25$ & $49.98 \pm 0.19$ & $99.97 \pm 0.37$ & $25+25$ & $49.83 \pm 0.12$ & $99.66 \pm 0.24$ \\
\hline
\end{tabular}

${ }^{a}$ Six independent analyses. 
Table 7. Assay results of lisinopril in pharmaceutical preparation by the proposed methods and reference method ${ }^{10}$

\begin{tabular}{|c|c|c|c|c|c|}
\hline \multirow{2}{*}{$\begin{array}{l}\text { Item } \\
\text { Linvas tablets }(10 \mathrm{mg} \\
\text { lisinoprildihydrate per tablet })\end{array}$} & \multicolumn{3}{|c|}{ Kinetic Methods using ninhydrin } & \multirow{2}{*}{$\begin{array}{c}\text { Ascorbic } \\
\text { acid method }\end{array}$} & \multirow{2}{*}{$\begin{array}{r}\text { Reference } \\
\text { method }\end{array}$} \\
\hline & $\begin{array}{l}\text { Initial rate } \\
\text { method }\end{array}$ & $\begin{array}{l}\text { Rate constant } \\
\text { method }\end{array}$ & $\begin{array}{l}\text { Fixed time } \\
\text { method }\end{array}$ & & \\
\hline Recovery $(\%)^{\mathrm{a}}$ & 99.55 & 99.04 & 100.70 & 100.43 & 99.57 \\
\hline $\operatorname{RSD}(\%)^{\mathrm{a}}$ & 1.57 & 0.75 & 1.19 & 0.63 & 1.00 \\
\hline$t$-value & 0.0321 & 1.580 & 1.81 & 1.6867 & \\
\hline$F$-value & 3.59 & 1.79 & 1.33 & 2.53 & \\
\hline$\theta_{\mathrm{L}}^{\mathrm{b}}$ & 0.9865 & 0.9876 & 0.9989 & 0.9828 & \\
\hline$\theta_{\mathrm{U}}^{\mathrm{b}}$ & 1.0140 & 1.0044 & 1.0117 & 1.0001 & \\
\hline \multicolumn{6}{|l|}{$\begin{array}{l}\text { Listril tablets ( } 10 \mathrm{mg} \text { lisinopril } \\
\text { dihydrate per tablet) }\end{array}$} \\
\hline Recovery $(\%)^{\mathrm{a}}$ & 98.96 & 99.49 & 100.40 & 99.45 & 98.88 \\
\hline $\operatorname{RSD}(\%)^{\mathrm{a}}$ & 1.44 & 0.59 & 1.20 & 0.67 & 0.81 \\
\hline$t$-value & 0.1550 & 1.523 & 0.7900 & 1.1853 & \\
\hline$F$-value & 3.13 & 2.85 & 1.17 & 1.47 & \\
\hline$\theta_{\mathrm{L}}^{\mathrm{b}}$ & 0.9870 & 0.9864 & 0.9873 & 0.9865 & \\
\hline$\theta_{\mathrm{U}}^{\mathrm{L}}$ & 1.0115 & 1.0012 & 1.0047 & 1.0020 & \\
\hline
\end{tabular}

${ }^{a}$ Six independent analyses; Theoretical $t$-value $(D f=10)$ and $F$-value $(D f=5,5)$ at $95 \%$ confidence level are 1.812 and $5.05 .{ }^{32} ;{ }^{b}$ In pharmaceutical analysis, a bias, based on recovery experiments, of $\pm 2 \%$, i.e., $\theta_{L}=0.98$ and $\theta_{U}=1.02$ is acceptable. ${ }^{31}$

ninhydrin was found to be highly selective for the determination of lisinopril at $25{ }^{\circ} \mathrm{C}$. The acidic degradation product was found not to react significantly with ninhydrin in DMF medium at room temperature and is tolerable up to $90 \%$.

\section{Conclusion}

Though both the methods are suitable for the routine analysis of lisinopril in commercial dosage forms but the ascorbic acid method is economical in comparison to the ninhydrin method. However, the ninhydrin method is selective for lisinopril and is suitable for the analysis of lisinopril in pure as well as commercial dosage forms in the presence of its acidic degradation product.

\section{Acknowledgement}

The authors are thankful to the Chairman, Department of Chemistry, Aligarh Muslim University, Aligarh, for providing the research facilities and to $\mathrm{M} / \mathrm{s}$ Zydus Cadila Healthcare Limited, India for the gift sample of pure lisinopril. One of the authors (M.N. Hoda) is also thankful to C.S.I.R., India, for the continuous financial assistance by awarding Senior Research Fellowship.

\section{References}

1. Rzen, J.; Senica, D.; Acta Chim. Slov. 2001, 48, 597.

2. El-Gindy, A.; Ashour, A.; Abdel-Fattah, L.; J. Pharm. Biomed. Anal. 2001, 25, 913.

3. Rajasekaran, A.; Murugesan, S.; Asian J. Chem. 2001, 13, 1245.
4. Hillaert, S.; Van den Bosscha, W.; J. Chromatogr: A 2000 , $895,33$.

5. Gotti, R.; Adrisano, V.; Cavrini, V.; J. Pharm. Biomed. Anal. 2000, 22, 423.

6. Ouyang, J.; Baeyens, W. R. G.; Talanta 1998, 46, 961.

7. Sane, R. T.; Valiyare, G. R.; Deshmukh, U. M.; Singh, S. R.; Indian Drugs 1992, 29, 558.

8. United States Pharmacopoeia XXIII, National Formulary 18, United State Pharmacopoeial Convention: Rockville, MD, 1995, p. 895.

9. European Pharmacopoeia, Council of Europe, 1997, 1105.

10. El-Yazbi, A. F.; Abdine, H. H.; J. Pharm. Biomed. Anal. 1999, 19,819 .

11. Iskender, G.; Yarenci, B.; Acta Pharm. Turc. 1995, 37, 5.

12. Atmaca, S.; Tatar, S.; Iskender, G.; Acta Pharm. Turc. 1994, 36, 13.

13. Abdel Razak, O.; Belal, S.F.; Bedair, M. M.; Barakat, N. S.; Haggag, R. S.; J. Pharm. Biomed. Anal. 2003, 31, 701.

14. El-Emam, A. A.; Steen Honore Hansen; Moustafa, M. A.; ElAshry, S. M.; El-Sherbiny, D. T.; J. Pharm. Biomed. Anal. 2004, 34, 35.

15. Panzade, P. D.; Mahadek, L. R.; Indian Drugs 1999, 36, 321.

16. Rajasekaran, A.; Udayavani, S.; J. Indian Chem. Soc. 2001, 78, 485.

17. Prasad, C. V. N.; Saha, R. N.; Parimoo, P.; Pharm. Pharmacol. Commun. 1999, 5, 383.

18. Jain, H. K.; Agrawal, R. K.; Indian Drugs 2000, 37, 196.

19. Erk, N.; Spectrosc. Lett. 1998, 31, 633.

20. Ozer, D.; Senel, H.; J. Pharm. Biomed. Anal. 1999, 21, 691.

21. Espinosa-Mansilla, A.; Acedo-Valenzuela, M. I.; Salinas, F.; Canada-Canada, F.; Analytica Chimica Acta 1998, 376, 365.

22. Fiegel F.; Spot Tests in Organic Analysis, Elsevier Publishing Co.: London, 1960. 
23. Rahman, N.; Azmi, S. N. H.; IL Farmaco 2001, 56, 731.

24. Rahman, N.; Kashif, M.; IL Farmaco 2003, 58, 1045.

25. Campins-Falco, P.; Sevillano-Cabza, A.; Gallo-Martinez, L.; Bosch-Reig, F.; Anal. Chim. Acta 1996, 324, 199.

26. Snell, F. D.; Snell, C. T.; Colourimetric Methods of Analysis (Including Photometric Methods), D. Van Nostrand Company, Inc.: Princeton, New Jersey, London, 1967, 4-A, p. 243.

27. Rahman, N.; Hoda, M.N.; J. Pharm. Biomed. Anal. 2003, 31, 381.

28. McCaldin, D.J.; Chemical Review 1960, 60, 39.

29. Sandulescu, R.; Mirel, S.; Oprean, R.; J. Pharm. Biomed. Anal. 2000, 23, 77 .
30. Miller, J.N.; Miller, J.C.; Statistics and Chemometrics for Analytical Chemistry, Pearson Education Limited: England, 2000.

31. Hartmann, C.; Smeyers-Verbeke, J.; Penninckx, W.; Heyden, Y.V.; Vankeerberghen, P.; Massart, D.L.; Anal. Chem. 1995, 67, 4491.

32. Vogel, A. I.; Textbook of Quantitative Chemical Analysis, Pearson education (Singapore), Indian branch: New Delhi, 2002, p. 777 and 778.

Received: January 6, 2005 Published on the web: August 3, 2005 